\title{
AFRICA REVIEW
}

\section{AN UP-TO-DATE GEOGRAPHICAL, HISTORICAL, POLITICAL AND ECONOMIC SUMMARY OF THE AFRICAN COUNTRIES}

Prepared by : F. Pauwels, P. Van Damme, D. Theeten, C. De Keyser, S. Hoste, P. Wymeersch.

\section{RWANDA}

1. Official name: Republic of Rwanda

Republika y'Urwanda

2. Geography:

2.1. Situation: in the heart of Central Africa between 140 'S and $248^{\prime} S$, $28^{\circ} 50^{\prime} \mathrm{E}$ and $30^{\circ} 54^{\prime} \mathrm{E}$.

\subsection{Total area: $26.338 \mathrm{~km}$.}

2.3. Natural regions: a dissected highland country declining from west to east (average altitude $1500 \mathrm{~m}$ ). The edge of the plateaux rises in the west to $3000 \mathrm{~m}$ and divides the watersheds of the Zaire and the Nile. In the northwest lies a range of volcanoes, culminating in the Karisimbi peak at $4507 \mathrm{~m}$.

2.4. Climate: tropical with a well-marked dry season of about 3 months between June and August. While annual rainfall amounts vary only slightly, the rainfall in some months can be very uncertain particulary in September at the time when crops are sown. The failure or inadequacy of the rains often lead to food scarcety or even famine. 


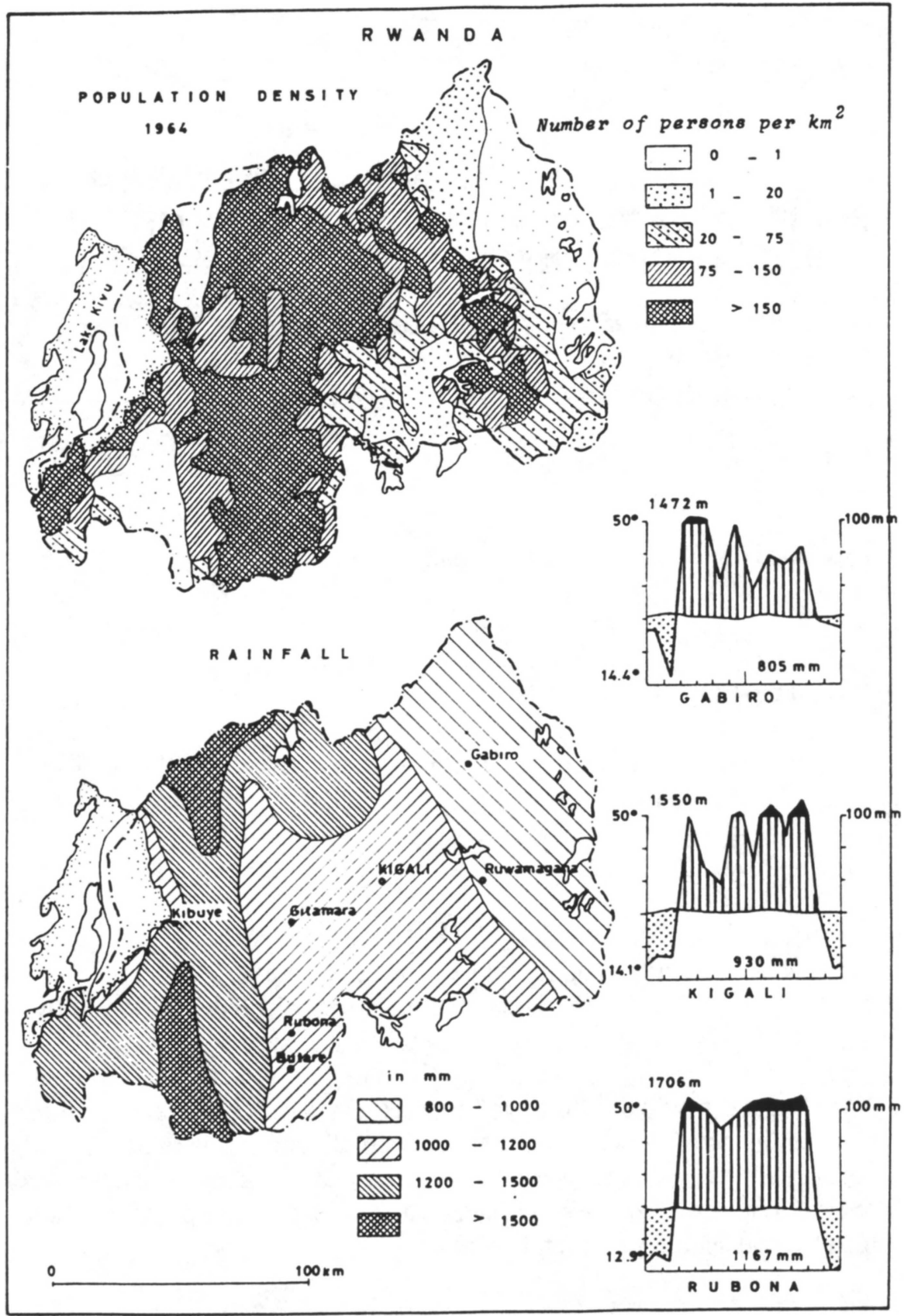


3. Population:

3.1. Total population: $6.7 \mathrm{mln}$ (1988), urban population: $5 \%$.

3.2. Population density: 260 per $\mathrm{km}^{2}$. (1988).

3.3. Population growth rate: $3.3 \%$ (1988).

3.4. Capital: KIGALI, 118.000 inh. (1978).

3.5. Languages: Kinyarwanda, French (official), Swahili.

3.6. Religion: Christians $45 \%$, traditional beliefs $44 \%$, small Islamic community

\section{History:}

The Twa pygmies are believed to have been the autochtonous population. Hutu (agriculturalists) and Tutsi/Hima (pastoralists) immigrated. The latter (from Nilotic origin) conquered the country between the 13th and 15th century. Rwanda was one of the kingdoms of interlacustrine Africa and ruled by divine kings (Bami) under one of the five cyclical and dynastical names (Mutara, Kigeri, Mibambwe, Yuhi, Cyirima).

According to the genealogy, fourthy of them ruled since the Tutsi invasion. The symbol of power and authority was the sacred drum (Karinga). Clientship (Ubuhake) between Tutsi and Hutu played an important role on economical, social and political levels. The administration was based upon hierarchy and the country was ruled by political specialists, the army and the Queen Mother. The ritualists (Abiru) were magico-religious specialists from the court; they took care of the continuity of kingship. The Tutsi were the leading ethnic group till 1959 when the Hutu revolted. Rwanda was a part of the German colonial territory from 1899 to 1917 and became a mandate under Belgian administration from 1920 until independence in 1962.

5. Nature of political system:

The president is both Head of State and President of the sole legal party, the "Mouvement révolutionaire national pour le développement" (MRND). He is elected for a five-year term and can be re-elected provided he is not over 


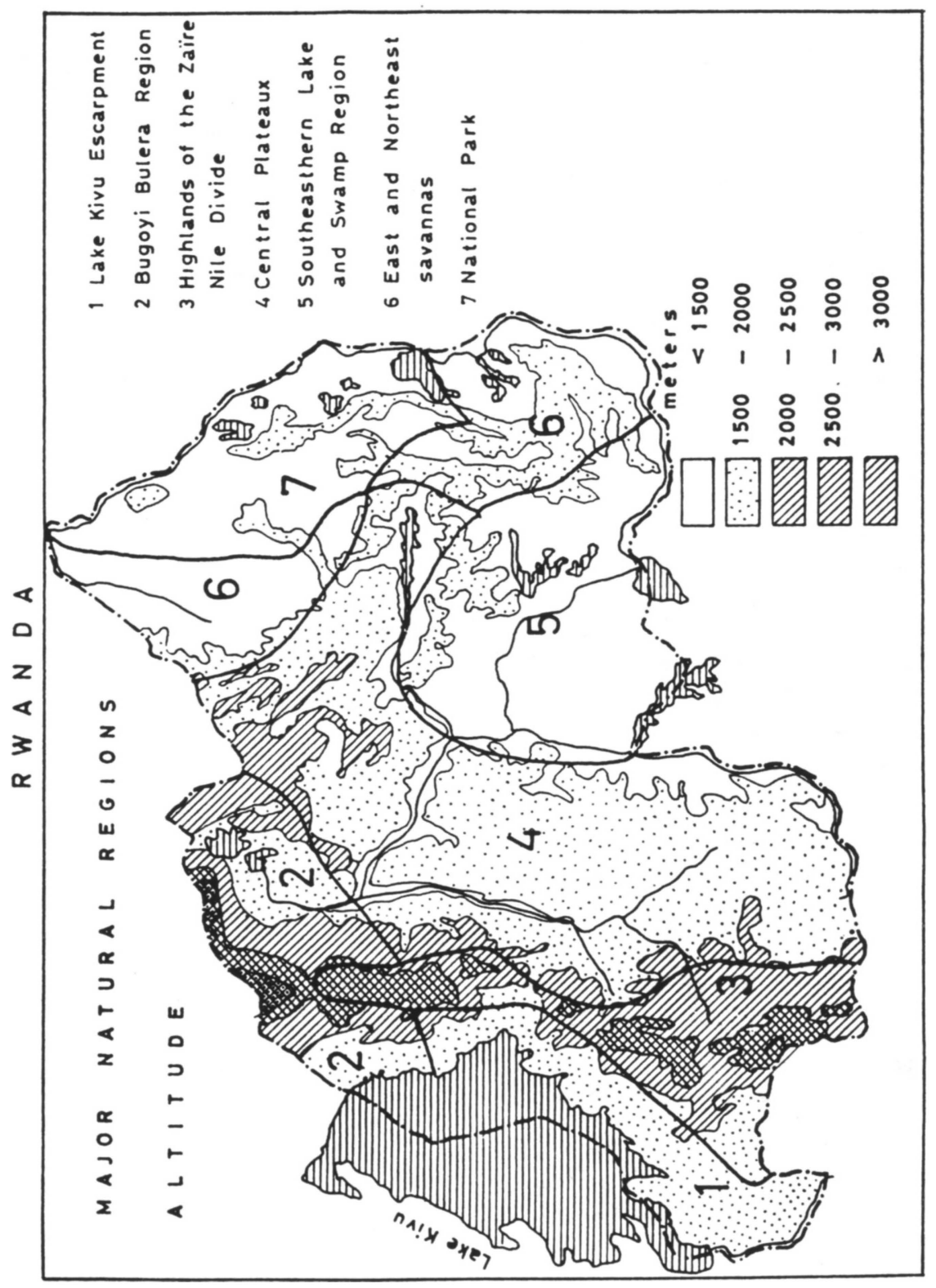


60 years old. In case of the President's death or incapacity to hold office, the secretary-general of the "MRND" acts as interim-president until a new one is elected (within 90 days). The president nominates his ministers and presides the Council of Ministers.

Legislative power resides by the President and the National Development Council (elected for five years by universal suffrage). The Council may veto the president's decisions by a vote of four- fifths of its members.

\section{Economy:}

GDP: agriculture: $45 \%$, industry: $22 \%$, services: $34 \%$ (1985).

Employment: agriculture: $91 \%$, industry: 2\% (1980).

\subsection{Mining:}

Casserite and wolframite represent $95 \%$ of the mineral ore exports. Natural gas reserves under Lake Kivu are said to be "massive".

\subsection{Agriculture:}

$38 \%$ of the total area is arable land or cultivated with permanent crops (1984). A wide range of crops is grown because of the special combination of tropical climate and high altitude. Main foodcrops are beans, peas, groundnut, sorghum, millet, potatoes and sweet potatoes, maize, cassava and bananas. These crops are almost entirely cultivated at subsistence level for domestic consumption. Little more than $10 \%$ of production is surplus for cash sale. Coffee, tea and barley (for beer production) are the main industrial crops. Export crops are arabica coffee, robusta coffee, pyrethrum and tea.

\subsection{Livestock:}

$16 \%$ of the total area is permanent pasture (1984). As in other African countries cattle raising plays an important role in the social structure. There is, however, hardly any selection, limited value in terms of food production local overstocking. There are about 900000 goats, 645000 heads of cattle, 300000 sheep, 130000 pigs and a large number of rabbits and poultry.

\subsection{Forestry and woodland:}

$19 \%$ of the total area (1984). The extent of the natural forest is limited to the Zairre-Nile watershed and the volcanic regions. Reforestation with eucalyptus and pine. 


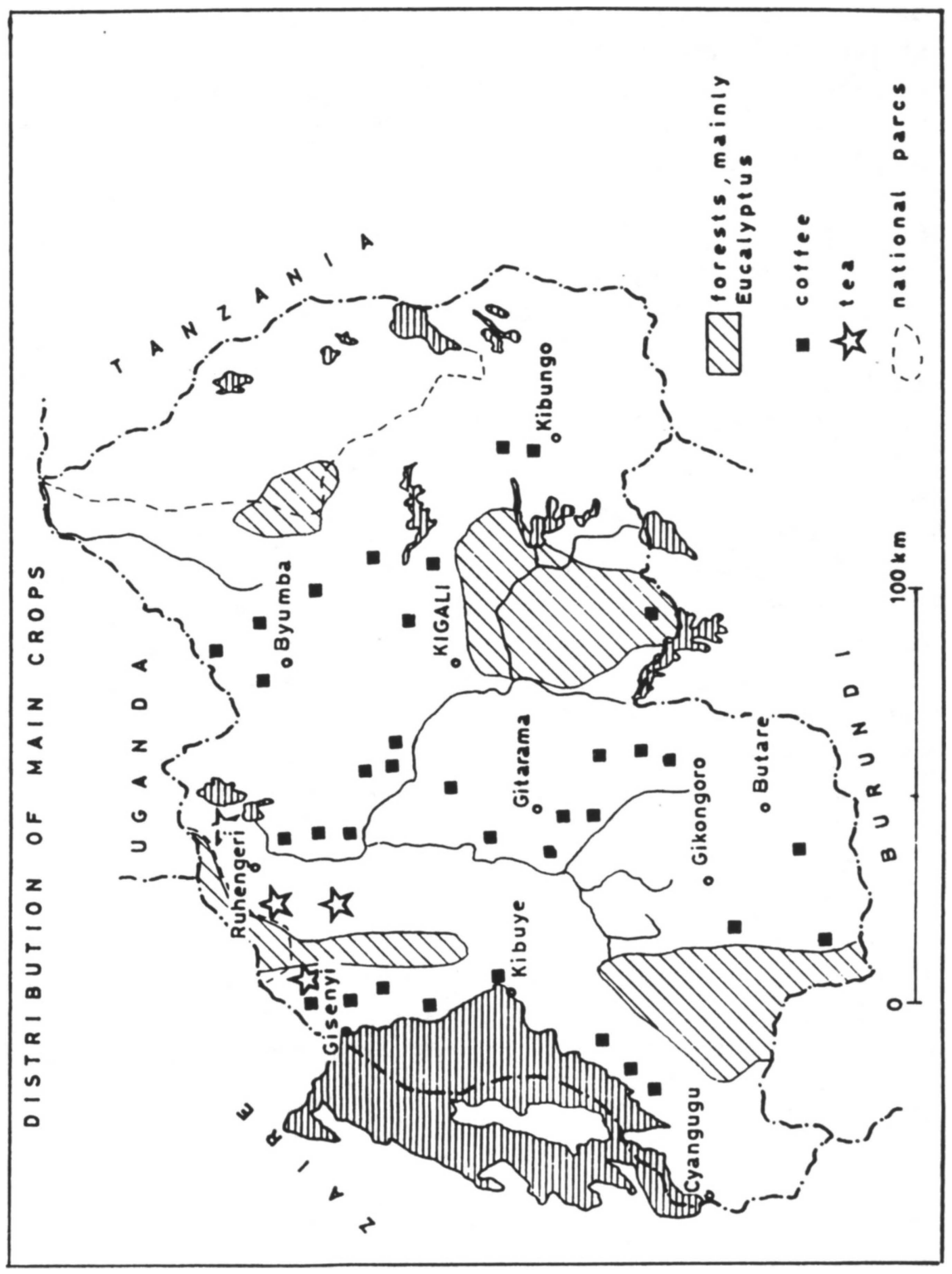




\subsection{Fishery:}

Annual lake catch is about $1000 \mathrm{t}$, exclusively for local markets. 6.6.Industry:

Processing of agricultural products: manufacturing of coffee, tea and pyrethrum, brewing of beer and soft drinks, soap factories.

\subsection{Weights, measures and currency:}

$\mathrm{kg}$, meter

1 Franc (R.Fr.) $=100$ centimes

1 US \$ = 76.45 R.FR.C (1988)

\section{Trade:}

Total exports amount to $75 \mathrm{mln}$ US \$(1985), mostly agricultural products. Main clients are the EEC, the USA, Kenya, Japan and Iran.

Total imports amount to $235 \mathrm{mln}$ US \$ (1985) of which food represents $12-15 \%$, machinery and tools $13-14 \%$ and transport equipment $11-13 \%$. Main suppliers the EEC, the USA, Kenya, Tanzania and Zaire.

\section{Miscellaneous:}

Literacy: male: $61 \%$, female: $39 \%$.

World Bank classification: Rwanda belongs to the low-income economies with a GDP per capita of 280 US \$ (1985).

Membership of intemational organisations:

GATT, ILO, IMF, OAU, UN, WHO, African Development Bank, Arab Bank for Economic Development in Africa (recipient), Economic Commission for Africa, World Bank.

Embassy of Rwanda in Belgium: Bloemenlaan 1

$$
1150 \text { Brussel }
$$

Tel. 02/763.07.02

Belgian Embassy in Rwanda: rue Nyarugence

B.P. 81

Kigali, Rwanda 


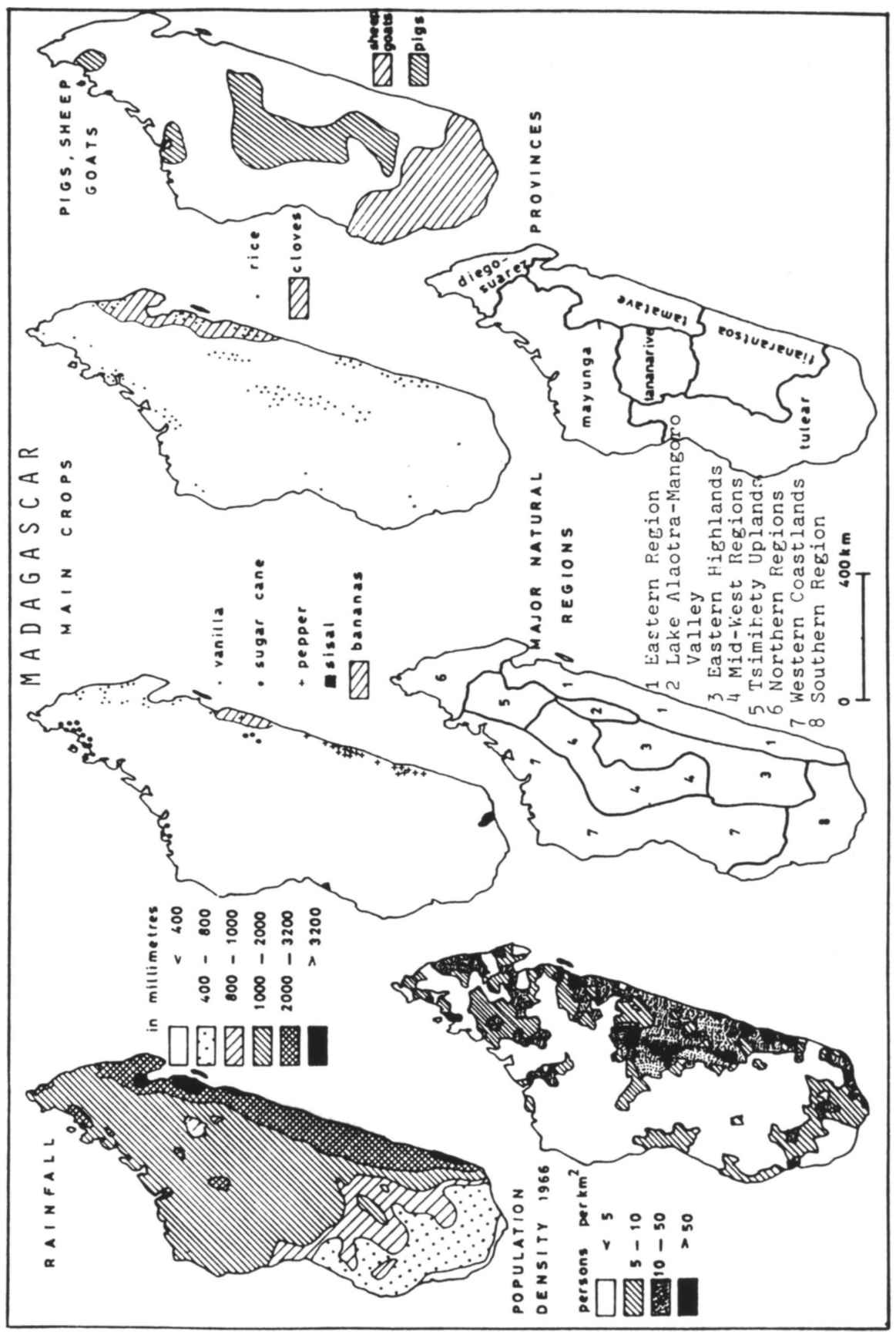

